\title{
Translocations Involving Tyrosine Kinases or Cytokine Receptors Present
}

National Cancer Institute

\section{Source}

National Cancer Institute. Translocations Involving Tyrosine Kinases or Cytokine

Receptors Present. NCI Thesaurus. Code C129789.

A cytogenetic finding indicating the presence of translocations involving either tyrosine kinases or cytokine receptors. 